\title{
ETNO-ETIK TANEAN LANJHENG: KONSTRUKSI ETOS BISNIS KELUARGA MUSLIM MADURA
}

\author{
Oleh: \\ Firman Setiawan \& Sirajul Arifin \\ Universitas Trunojoyo Madura, Indonesia \\ Universitas Islam Negeri Sunan Ampel Surabaya, Indonesia, Indonesia \\ firman.setiawan@trunojoyo.ac.id \\ sirajul.arifin@uinsby.ac.id
}

\begin{abstract}
:
The Madurese are one of the ethnic groups in Indonesia who have a unique character, namely religious, hard-tempered, firm, brave, upholding self-esteem, and have high solidarity and brotherhood. From these characters then emerged and known one character that is quite amazing from the ethnic Madurese, which has a high work ethic. This can be seen for example from their perseverance in fighting for their socio-economic life. Even when Madura's natural conditions do not allow exploitation to improve their economic lives, migrating is one of the paths taken. Their strong work ethic can be genetically acquired, but it is also very likely to be influenced by the religion and socio-culture that develops in their environment. Especially for those who live in families who live in an environment known as tanean lanjhang. Growing culture and very close family ties in this environment have resulted in the transfer of religious values and work ethics from parents to their juniors to be very effective. The characteristics and work ethics of Madurese, especially those who live and live in the Tanean Lanjhang environment, are ambitious and hard-working, have high solidarity, are responsible and work-oriented. If seen from the religious understanding adopted and believed by the Madurese people, that human actions have something to do with the provisions of God, but God gives the human potential to try and endeavor. This is what then makes Madurese so persistent in fighting for their socio-economic life even though natural conditions do not allow exploitation and maximum utilization. This understanding is inseparable from the teachings that are so deeply rooted in Muslim circles of Madura, they are Ahlu Sunnah Waljama'ah alNahdliyah.
\end{abstract}

Keywords : Etos Bisnis, Tanean Lanjheng. Budaya Madura 


\section{A. Pendahuluan}

Indonesia adalah negara yang kaya "gemah ripah loh jinawi". Kekayaan tersebut tidak hanya berupa kekayaan hasil alam, tetapi juga suku dan etnis yang beragam. Menurut data BPS tahun 2010, Indonesia memiliki 1.340 suku, walaupun tidak ada ketentuan yang pasti untuk pembagian ini akibat migrasi penduduk dan percampuran budaya sehingga keberadaan dan percampuran etnis ini saling mempengaruhi satu sama lain.

Masing-masing etnis dan suku yang ada di Indonesia tentu memiliki karakter dan keunikan, seperti bahasa, agama, kepercayaan dan adat istiadat. Mentalitas dan pola kehidupan yang dimiliki juga berbeda antara satu etnis dengan etnis lainnya. Keunikan mentalitas dan pola kehidupan itu pada akhirnya juga berdampak pada keanekaragaman kegiatan ekonomi, sosial dan budaya.

Suku Madura adalah salah satu etnis yang ada di Indonesia. Meski populasinya hanya sekitar 3,03\% dari keseluruhan populasi etnis yang ada di Indonesia, namun suku Madura cukup mewarnai dan menjadi perhatian dalam hal budaya dan sosial. Hal ini karena keunikan dan karakter yang kental dari suku Madura.

Suku Madura dikenal sebagai masyarakat yang sangat kental dengan sikap religiusnya.1 Hal ini bisa dilihat dari misalnya bagaimana mereka betul-betul menjaga keluarga/anak-anaknya dari pergaulan yang dianggap tidak baik secara adat dan agama, ta'dzimnya kepada para guru dan kiai (terutama kiai kampung tempat mereka belajar ngaji)2, pandangan sebagian besar masyarakat Madura bahwa menjalani pendidikan di pesantren adalah kewajiban yang tidak bisa ditawar, dan bahkan untuk hal-hal yang barangkali sepele tetapi jika berkaitan dengan agama maka menjadi perhatian yang serius. Seperti melakukan ritual do'a

1 Tingkat religiusitas orang Madura berbeda-beda antara satu individu dengan individu lainnya. Namun adat istiadat yang lahir dari dialektika agama dan budaya lokal hingga begitu kental dengan ajaran Islam menjadi bukti bahwa orang Madura hidup dalam atmosfer religiusitas yang tinggi.

2 Bahkan lembaga agama dan para ulama lebih dihormati dan disegani dari pada lembaga negara dan aparatnya. Karena itu, tidak jarang program pemerintah yang mengabaikan keterlibatan kiai setempat tidak berakhir dengan sukses. Hal ini karena program yang tidak melibatkan atau setidaknya mendapat restu dari kiai cenderung tidak didukung oleh masyarakat. Muhammad Djakfar, "Etos Bisnis Etnis Madura Perantauan Di Kota Malang: Memahami Dialektika Agama Dengan Kearifan Lokal," Iqtishoduna 7, no. 2 (April 9, 2012), accessed September 20, 2019, http://ejournal.uinmalang.ac.id/index.php/ekonomi/article/view/1739.

$174 \mid$ JURNAL LISAN AL-HAL 
sebelum memulai usaha, rumah baru tidak akan ditempati dan kendaraan baru tidak akan dikendarai sampai dilakukan selamatan, dan lain sebagainya.

Indikasi ketaatan mereka dalam beragama juga bisa dilihat dari cara berpakaian atau menutup aurat. Orang Madura memiliki corak tersendiri dalam berpakaian terutama masyarakat pedesaan, seperti samper (kain panjang untuk penutup tubuh bagian bawah/dari pinggang hingga ke kaki), kebaya, dan burgo' (kerudung) bagi perempuan, serta sarong (sarung) dan songkok (kopiah atau peci) bagi laki-laki.3

Pandangan hidup orang Madura dalam beragama menuntunnya menjalani kehidupan untuk mencapai kebahagiaan dunia dan akhirat. Untuk itulah, berikhtiar menjadi menjadi sangat penting bagi orang Madura, sebab pendekatan ini memperbesar kemungkinan untuk mencapai semua keinginan dan tujuan.4

Selain sikap religiusnya, suku Madura juga memiliki karakter yang unik. Bukan hanya stigma dan image yang melekat pada suku Madura sebagai orang yang berwatak keras dan suka melakukan carok, tetapi juga karena sifatnya yang tegas, berani, menjunjung tinggi harga diri, solidaritas dan persaudaraan yang kuat, hormat pada orang yang dituakan serta memiliki kegigihan dan semangat juang yang tinggi dalam memperjuangkan kehidupan sosial ekonominya. ${ }^{5}$

Kegigihan orang Madura dalam memperjuangkan kehidupan sosial ekonominya bisa dilihat dari semangat dan dorongan bagi mereka untuk merantau. Karena itu, hampir di seluruh wilayah di Indonesia ada orang Madura. Hal ini karena kegigihan mereka tidak diimbangi dengan kondisi alam Madura (atau kemapanan SDM) sehingga mengharuskan mereka meninggalkan kampung halaman. Kelangkaan sumber daya alam menyebabkan para petani di Madura tidak percaya pada tanah, tetapi pada

${ }^{3}$ A. Latief Wiyata, Mencari Madura (Jakarta : Bidik-Phronesis Publishing, 2013), 3. Pakaian tersebut tidak hanya menjadi simbol identitas orang Madura, tetapi juga merupakan lambang kesopanan, adat istiadat dan tata krama. Misalnya seseorang yang sowan/menghadap orang yang dituakan atau kiai dengan menggunakan celana jeans dianggap tidak sopan, bahkan bisa dianggap aneh, karena semestinya menggunakan sarung dan peci.

${ }^{4}$ A. Latief Wiyata, Mencari Madura... 4.

5 Karena itu, melakukan hal-hal yang bertentangan dengan sifat-sifat itu, seperti dhalmos (malas bekerja baik untuk mencari nafkah atau untuk pekerjaan rumah), lampot (memiliki makna yang sama dengan dhalmos, yakni malas. Hanya saja kata lampot ini digunakan untuk orang yang tidak bisa dimintai bantuan), tak esto (tidak memiliki kepedulian pada orang lain), janggal (tidak sopan) dan korang ajhar (kurang ajar), adalah hal yang sangat memalukan dan dianggap menjatuhkan harga dirinya. 
kerja. Dengan kata lain, spirit kerja di kalangan petani Madura tidak berorientasi pada tanah (land ethics), melainkan spirit yang berorientasi pada kerja (labour ethics ). Karena itu, jika tanah/lahan pertanian di kampung halamannya dianggap tidak bisa diandalkan, dengan mudah bagi mereka kemudian pergi untuk merantau. ${ }^{6}$

Kemandirian orang Madura dalam bidang usaha (baik yang ada di Madura maupun di perantauan) tidak diragukan lagi. Hal ini karena etos (keuletan, kegigihan dan kerja keras) orang Madura dalam bekerja begitu luar biasa. Etos bisnis ini yang kemudian terdokumentasi dalam peribahasa "abantal omba' asapo' angin (berbantal ombak dan berselimut angin)". ${ }^{7}$

Etos bisnis orang Madura yang sebegitu kuat, bisa saja terbentuk karena faktor genetik, namun jika melihat fakta sebagaimana yang dipaparkan di atas, sangat mungkin jika etos bisnis mereka dipengaruhi oleh faktor ajaran dan doktrin agama yang mereka yakini, faktor sosialbudaya dalam kehidupan mereka sehari-hari atau kombinasi dari keduanya. ${ }^{8}$

Pengaruh agama dan sosial budaya ini akan semakin tampak manakala melihat kehidupan keluarga Madura yang tinggal di beberapa rumah dengan jarak yang sangat berdekatan hingga bisa menggunakan satu halaman saja, yang dikenal dengan istilah tanean lanjhang. Pengaruh agama dan sosial budaya akan terasa sangat kuat di keluarga tanean lanjhang karena doktrin dari keluarga (bahkan dari beberapa generasi) yang dilakukan sejak kecil, terutama dalam masalah etika. Karena hal inilah kenapa kemudian karakter, sifat dan etos yang dimiliki oleh orang Madura menjadi sangat kuat dan mengakar. Oleh karena itu, melalui Paper ini penulis ingin mengungkap bagaimana etos bisnis keluarga muslim tanean lanjhang di Madura.

\section{B. Metode}

Penelitian ini termasuk ke dalam penelitian bibliografis atau literature study, karena penelitian ini dilakukan untuk mencari, menganalisis, membuat interpretasi, serta generalisasi dari fakta-fakta, hasil pemikiran, dan ide-ide yang telah ditulis oleh para pemikir dan ahli. ${ }^{9}$ Maka data-data yang digunakan dalam penelitian ini berupa teks literatur dari beberapa buku dan jurnal ilmiah yang dikumpulkan dengan metode dokumentasi.

6 Totok Rochana, “Orang Madura: Suatu Tinjauan Antropologis,” Humanus 11, no. 1 (2012): 46-51.

7 Djakfar, "ETOS BISNIS ETNIS MADURA PERANTAUAN DI KOTA MALANG."

${ }^{8}$ Ibid.

${ }_{9}^{9}$ Rianto Adi, Metodologi Penelitian Sosial dan Hukum (Jakarta: Granit, 2004), 61.

$176 \mid$ JURNAL LISAN AL-HAL 


\section{Pembahasan}

\section{Etos Kerja}

Kata etos berasal dari Bahasa Yunani, etos yang berarti adat kebiasaan, watak (karakter), moral (etika), dan cara mengerjakan sesuatu. ${ }^{10}$ Dari kata ini pula kemudian lahir kata etika atau etiket yang berarti semangat yang kuat dalam mengerjakan sesuatu secara optimal,11 sehingga spirit dalam pekerjaannya adalah menghasilkan manfaat semaksimal mungkin dan meminimalkan bahkan menghilangkan cacat/kerusakan.

Etos kerja merupakan pemahaman dan doktrin tentang kerja yang dimiliki dan diyakini oleh seseorang dan/atau sekelompok orang sebagai sesuatu yang baik dan benar yang kemudian terimplementasikan dalam perilaku kerja mereka. Menurut Max Weber, etos kerja adalah keyakinan yang berfungsi sebagai panduan tingkah laku seseorang, sekelompok atau sebuah institusi. Maka memahami dan meyakini etos kerja sebagai bagian dari ajaran dan doktrin agama, merupakan perwujudan sikap diri dalam bekerja serta merupakan implementasi dan internalisasi nilai-nilai religius sehingga menjadi spirit bagi seseorang agar dapat melakukan yang terbaik untuk pekerjaan yang sedang dijalani. ${ }^{12}$

Adapun etos kerja dalam pandangan islam, Toto Tasmara dalam bukunya Etos Kerja Pribadi Muslim mendefinisikan etos kerja sebagai cara pandang yang dipahami dan diyakini seorang muslim bahwa bekerja itu tidak hanya untuk memuliakan dirinya, bukan saja dalam rangka menampakkan sisi kemanusiaannya, tetapi juga sebagai suatu perwujudan amal shaleh dan karenanya mempunyai nilai ibadah di hadapan Allah SWT. ${ }^{13}$

Dalam islam, etos kerja juga dipahami sebagai seperangkat prinsip yang dapat membedakan antara yang benar dan yang salah.14 Dengan

10 Wasisto Raharjo Jati, "Agama Dan Spirit Ekonomi: Studi Etos Kerja Dalam Komparasi Perbandingan Agama,” AL QALAM 35, no. 2 (December 31, 2018): 211-240.

11 Didi Sunardi, "Etos Kerja Islami," JISI: Jurnal Integrasi Sistem Industri 1, no. 1

(February 2, 2014), accessed $\quad$ September 10, 2019,
https://jurnal.umj.ac.id/index.php/jisi/article/view/928.

12 Mohammad Irham, “Etos Kerja Dalam Perspektif Islam," SUBSTANTIA 14, no. 1 (April 11, 2012): 9-24.

13 Ibid.

14 Wahibur Rokhman, “The Effect of Islamic Work Ethics on Work Outcomes," EJBO

- Electronic Journal of Business Ethics and Organization Studies (2010), accessed December 3, 2019, https://jyx.jyu.fi/handle/123456789/25449. 
pemahaman yang demikian, maka etos kerja berfungsi sebagai panduan untuk berbuat kebajikan dalam bekerja. Panduan tersebut merupakan ajaran yang bersumber dan al-Qur'an dan al-Sunah.

Berdasarkan pemaparan di atas dapat dipahami bahwa etos kerja adalah doktrin dan cara pandang yang diyakini, memotivasi dan menggerakkan seseorang bahwa pekerjaan harus dilakukan dengan cara terbaik, sehingga setiap perilaku dalam pekerjaannya merupakan manifestasi dari keyakinan tersebut.

\section{Faktor-Faktor Yang Membentuk Etos Kerja}

Etos kerja bukan hanya bentuk fisik lahiriah saja. Etos kerja merupakan sikap yang tumbuh dan memancar dari dinamika kejiwaan seseorang sebagai buah atas keyakinan yang dimilikinya. Oleh karena itu, etos kerja tinggi yang tidak didorong oleh kondisi psikologis yang kuat sama halnya seperti kerja robot atau makhluk tanpa jiwa. Dalam konteks ini, tentu saja bukan etos kerja seperti itu yang dikehendaki. Manusia merupakan makhluk biologis, sosial, intelektual, spiritual dan pencari Tuhan. ${ }^{15}$ Karena itu tindaknya haruslah merupakan manifestasi dari sikap jiwa dan pemikirannya.

Jika etos kerja adalah manifestasi dari dinamika kejiwaan seseorang, maka beberapa faktor berikut memiliki peran yang sangat penting dalam pembentukan etos kerja seseorang.

a. Religion (Agama)

Salah satu teori dalam masalah ini menyatakan bahwa kerja terkait dengan sistem kepercayaan/agama, berdasarkan fakta bahwa kelompok masyarakat tertentu yang memiliki sistem kepercayaan/agama tertentu memiliki etos kerja berbeda dari masyarakat yang memiliki sistem kepercayaan lain. ${ }^{16}$ Salah satu tokoh besar penggagas teori ini, yakni Max Weber, mengatakan dalam bukunya, "The Protestant Ethic and the Spirit of Capitalism", bahwa ada hubungan yang positif antara agama Kristen Protestan dengan etos kerja dalam membangun dan mengembangkan kapitalisme. ${ }^{17}$ Menurut Weber, penganut Protestan memiliki spirit yang kuat dalam mengumpulkan kekayaan dan mengejar sukses yang bersifat material karena hal itu dianggap sebagai bukti dari anugerah Tuhan pada

15 Erwin Jusuf Thaib, “Al-Qur'an Dan As-Sunnah Sebagai Sumber Inspirasi Etos Kerja Islami," Jurnal Dakwah Tabligh 15, no. 1 (June 16, 2014): 1-9.

16 Irham, "Etos Kerja Dalam Perspektif Islam."

17 Harjoni Desky, "Pengaruh Etos Kerja Islami Dan Gaya Kepemimpinan Terhadap Kinerja Karyawan Rumah Makan Ayam Lepaas Lhokseumawe," INFERENSI: Jurnal Penelitian Sosial Keagamaan 8, no. 2 (December 1, 2014): 459-478.

178 JURNAL LISAN AL-HAL 
mereka, sekaligus sebagai konfirmasi bahwa mereka adalah orang-orang pilihan Tuhan yang layak untuk diselamatkan di dunia dan di akhirat nanti. Maka sebagai perwujudan atas keyakinan tersebut, kaum Protestan di Jerman yang diamati Weber memiliki etos kerja yang unik seperti; berdisiplin tinggi, bekerja keras, bertindak rasional, hemat dan bersahaja, berorientasi pada sukses material, tidak mengumbar kesenangan serta menabung dan berinvestasi. ${ }^{18}$

Hal senada juga dikatakan Robert N. Bellah. Dari penelitian yang dilakukan olehnya terhadap masyarakat Jepang ditemukan fakta bahwa agama (Shinto, Budha dan Tao), terlebih di era Tokugawa memiliki andil dan pengaruh yang kuat terhadap seluruh aspek kehidupan, seperti perkembangan pendidikan, hukum, sains, politik dan termasuk juga pada aktivitas ekonomi. ${ }^{19}$

Dalam Islam, etos kerja dipandang sebagai spirit yang terkandung dalam ajaran islam itu sendiri, bahkan menjadi salah satu barometer dari tingkat keimanan dan keluhuran akidah seorang muslim.

Muhammad Tholchah Hasan dalam karyanya, Dinamika Kehidupan Religius, mengembangkan kajian etos kerja dari perspektif tasawuf, bahwa ada dua kategori posisi manusia terhadap kerja. Pertama, orang-orang yang berada pada maqam tajrid, yaitu orang yang merasa sudah tidak lagi membutuhkan kerja. Hal ini disebabkan beberapa faktor, misalnya masih terlalu muda/kecil untuk melakukan pekerjaan, sudah lanjut usia, berada pada posisi di mana dia sudah tidak lagi membutuhkan hal-hal yang bersifat duniawi yang mengharuskan dirinya bekerja, atau mungkin masih membutuhkan hal yang bersifat duniawi tetapi dia bisa mendapatkannya tanpa melalui bekerja. Kedua, orang-orang yang masih berada di maqam ikhtiyar, yaitu orang yang masih memiliki kebutuhan hidup yang tidak bisa dipenuhi kecuali dengan bekerja sementara dia memiliki kemampuan untuk bekerja. ${ }^{20}$

Dalam teologi islam, setidaknya ada tiga doktrin yang mempengaruhi etos kerja seseorang, yaitu :21

1) Faham Jabariyah (fatalisme).

Faham ini berpendapat bahwa manusia tidak memiliki kemerdekaan dan kemampuan untuk menentukan kehendak dan

18 Thaib, "Al-Qur'an Dan As-Sunnah Sebagai Sumber Inspirasi Etos Kerja Islami."

19 Muchammad Saifulloh, "Etos Kerja Dalam Perspektif Islam," Jurnal Sosial Humaniora 3, no. 1 (June 2, 2010): 54-69-69.

${ }^{20}$ Desky, "Pengaruh Etos Kerja Islami Dan Gaya Kepemimpinan Terhadap Kinerja Karyawan Rumah Makan Ayam Lepaas Lhokseumawe."

21 Saifulloh, "Etos Kerja Dalam Perspektif Islam." 
perbuatannya sendiri. Menurut faham ini, manusia terikat pada kehendak mutlak tuhan, sehingga manusia mengerjakan perbuatannya dalam keadaan terpaksa.

Nampaknya, paham jabariyah ini banyak dianut oleh bangsa Arab sebelum Islam, di mana mereka harus hidup dengan suasana padang pasir, sementara kehidupan mereka pada waktu itu serba sederhana dan jauh dari pengetahuan. Hal inilah yang kemudian memaksa mereka untuk menerima kenyataan dan pasrah dengan kehidupan di tengah padang pasir yang panas dan terik, serta tanah dan gunungnya yang gundul. Dalam kondisi yang demikian, mereka merasa tidak memiliki jalan dan kekuatan untuk dapat mengubah kehidupan dan keadaan sekelilingnya. Maka sikap pasrah dan merasa bahwa semua sudah merupakan ketentuan adalah sikap satu-satunya yang bisa diambil. ${ }^{22}$

2) Faham Qadariyah (free will).

Faham ini berpendapat bahwa perbuatan manusia merupakan kehendak dan diciptakan oleh manusia sendiri. Karena itu, perbuatan manusia tidak ditentukan dan diciptakan oleh Tuhan, sebaliknya manusia memiliki kehendak bebas dalam menentukan perbuatannya sendiri tanpa ada campur tangan (intervensi) dari Tuhan. Manusia mempunyai kekuatan sendiri dalam mewujudkan perbuatan-perbuatannya.

Menurut paham Qadariyah ini, manusia mampu mengubah kondisi sekeliling dan kehidupan mereka sendiri. Karena itu, mereka dituntut untuk berusaha dalam mempertahankan dan memperjuangkan hidup tanpa harus selalu bergantung pada ketentuan Tuhan.

3) Faham Sunni (Ahlu Sunnah wal Jama'ah)

Faham Sunni ini merupakan aliran jalan tengah dari dua faham sebelumnya yang saling bertolak belakang. Menurut Faham Sunni, perbuatan manusia ada kaitannya dengan ketentuan Allah, tetapi Allah memberikan manusia potensi untuk melakukan usaha dan ikhtiar. Jika usahanya sungguh-sungguh, manusia dapat mengubah nasibnya sendiri dengan izin Allah SWT.

b. Culture (Budaya)

Budaya merupakan watak dasar suatu masyarakat. Karenanya etos kerja suatu masyarakat juga mengakar dan tidak bisa lepas dari sistem kebudayaan tersebut. Hal ini terlihat dari fakta bahwa suatu masyarakat dengan sistem kebudayaan tertentu, memiliki etos kerja yang berbeda

22 Lihat juga Harun Nasution, Teologi Islam : Alira-aliran, Sejarah, Analisa Perbandingan (Jakarta : UI Press, 2012), 33-34.

$180 \mid$ JURNAL LISAN AL-HAL 
(lebih baik atau lebih buruk) dengan masyarakat lain yang juga memiliki sistem kebudayaan berbeda. ${ }^{23}$

Nilai budaya pada suatu masyarakat tertentu dan diwariskan secara turun-temurun, merupakan hasil pembelajaran dan didikan yang dilakukan para orang tua pada anak-anaknya sejak kecil. Sehingga nilai budaya ini tertanam kuat dan cukup mengakar pada generasi-generasi berikutnya dan menjadi karakter serta kepribadian mereka.

Karena budaya bukanlah nilai yang dapat diinternalisasi secara instan, maka demikian pula etos kerja yang dibentuk melalui pengaruh budaya tertanam sejak kecil, baik melalui keluarga, lingkungan, maupun pendidikan (formal dan non formal). Ketiganya memiliki peran terutama dalam pembentukan karakter diri, menjadi tempat mendisiplinkan diri, membentuk kepercayaan diri, menanamkan rasa saling menghormati, menanamkan budi pekerti yang luhur, serta membentuk seseorang menjadi pribadi yang bertanggung jawab.

c. Internalized Experience

Setiap orang memiliki pengalaman hidup yang mungkin berbeda dengan orang lain. Hal inilah yang kemudian juga menjadi sebab mengapa seseorang memiliki karakter dan dorongan jiwa yang berbeda untuk melakukan sesuatu. Bahkan pengalaman hidup seseorang sangat efektif dalam membentuk persepsi, motivasi dan tindakan seseorang.

Pengalaman yang pernah dihadapi sangat berpengaruh terhadap pikiran bawah sadar seseorang. ${ }^{24}$ Itulah mengapa setiap orang memiliki reaksi yang berbeda untuk satu hal yang sama.

Begitu juga kaitannya dengan pembentukan etos kerja seseorang. Misalnya seseorang yang pada masa lalunya pernah hidup miskin, serba kesusahan, bahkan dihina karena kemiskinannya bisa memiliki semangat "balas dendam" pada masa lalu yang pahit sehingga mampu mendorong etos kerjanya. Namun tentu saja tidak ada jaminan, bahwa orang yang pernah mengalami hal yang sebaliknya, akan melakukan hal yang sebaliknya juga. Seperti orang yang pada masa lalunya hidup kaya dan berkecukupan, kemudian tidak memiliki etos kerja yang tinggi. Hal ini karena memang belum ada penelitian yang secara spesifik dapat membuktikan seberapa besar pengaruh pengalaman seseorang dalam membentuk etos kerjanya.

23 Irham, "Etos Kerja Dalam Perspektif Islam."

24 Meski pikiran bawah sadar memiliki pengaruh terhadap perilaku seseorang, namun pengaruhnya tidak lebih dari $10 \%$ dari total pikiran seseorang. 


\section{Aspek-Aspek Etos Kerja Islami}

Etos kerja sebagai spirit dan perilaku seorang muslim, dapat dilihat dari beberapa aspek sebagai berikut : ${ }^{25}$

a. Aspek Aqidah

Iman atau keyakinan kepada Allah SWT memiliki peran yang sangat penting dalam menentukan tinggi rendahnya etos kerja seseorang. Karena pada dasarnya iman seseorang kepada Tuhannya akan membuat dirinya mampu memahami apa yang diinginkan dan dikehendaki olehNya. Pemahaman itu diperoleh melalui penghayatan terhadap ayat-ayat Allah (al-Qur'an dan hadits), sehingga al-qur'an dan hadits akan selalu menjadi pedoman dalam setiap aktivitas dan perbuatannya, tidak hanya dalam beribadah, tetapi juga dalam bermu'amalah.

Kualitas akidah seseorang akan tercermin dalam sikap hidup dan etos kerja yang dimilikinya, seperti menjunjung tinggi nilai-nilai kejujuran (QS. Al-Ahzab : 52), senantiasa ikhlas (QS. Al-Nisa' : 146), berorientasi pada mutu (al-Mulk : 2), selalu bertanggung jawab (QS. al-Mudatstsir : 38), berusaha meningkatkan kompetensi (al-Taubah : 105), dan konsisten (QS. Al-Nisa' : 58).

b. Aspek Ibadah

Menurut Yusuf Qardhawi, bekerja merupakan aktifitas yang bernilai ibadah di hadapan Allah SWT bahkan bernilai jihad di jalan Allah. Hal ini karena melalui amal usaha dan bekerja, masyarakat dapat melaksanakan risalah islam, melakukan da'wah, serta mewujudkan tujuan hidupnya, baik di dunia maupun di akhirat.

Sebagaimana dijelaskan dalam beberapa ayat dan hadits di atas bahwa seorang muslim yang bekerja dengan motivasi bahwa bekerja dan menafkahi keluarga adalah sebagian dari perintah Allah, maka perbuatan/pekerjaan muslim tersebut dapat bernilai ibadah. Islam menghendaki bahwa ibadah bukan hanya berupa ibadah ritual yang sifatnya hubungan langsung dengan Tuhan (hablum minallah), tetapi juga ibadah yang sifatnya berhubungan dengan manusia lainnya atau urusan duniawi, seperti bekerja dengan niat/tujuan untuk menafkahi keluarga dan memenuhi kebutuhan, sehingga seorang muslim tidak sampai menjadi pengangguran, peminta-minta atau menggantungkan pemenuhan hidupnya kepada orang lain.

25 Sunardi, “Etos Kerja Islami.”

182 JURNAL LISAN AL-HAL 
c. Aspek Mu'amalah.

Allah menyatakan dalam al-Qur'an bahwa salah satu tujuan manusia diciptakannya manusia adalah untuk menjadi khalifah di muka bumi agar mereka dapat menjaga, mengelola dan memakmurkannya. Oleh karena itu bagi seorang muslim, bekerja merupakan manifestasi dari fitrahnya sebagai manusia. Namun jika yang terjadi adalah sebaliknya, maka eksistensinya sebagai manusia menjadi tidak bermakna dan bernilai, baik di hadapan Allah SWT maupun di hadapan sesama manusia.

Kata "kerja" (dengan berbagai bentuknya) di dalam al-qur'an yang digandengkan dengan kata iman, "innaladhina amanu wa 'amilussalihat", disebutkan sebanyak 50 kali. Hal ini menunjukkan bahwa keimanan seseorang tidak akan diakui jika tidak diimbangi dengan amal shaleh. Dan di antara amal shaleh itu adalah bekerja untuk mendapatkan rizki yang halal.

Oleh karena itu, wajar kalau kemudian dikatakan bahwa eksistensi kehidupan seseorang ditentukan kualitas kerjanya. Semakin tinggi nilai dan kualitas kerjanya ${ }^{26}$, makin semakin tinggi juga kemuliaannya di hadapan manusia, lebih-lebih di hadapan Allah SWT.

\section{Filosofi Tanean Lanjhang}

Pola pemukiman penduduk di Madura, terutama rumah-rumah tempo dulu memiliki keunikan tersendiri, di mana rumah-rumah itu dibangun layaknya unit-unit sosial kecil, dengan formasi berjajar dan berhadap-hadapan, di ujung paling barat biasanya terdapat langgar, serta memiliki satu halaman panjang, karena itu kemudian disebut tanean lanjhang.

Secara bahasa, tanean artinya halaman, dan lanjhang berarti panjang. Disebut tanean lanjhang karena pada umumnya karena pada umumnya perumahan itu membentuk seperti kelompok dan berdekatan sehingga membutuhkan satu halaman saja yang berbentuk memanjang.

Biasanya, orang-orang yang tinggal di perumahan itu adalah satu keluarga besar atau kerabat. Rumah-rumahnya disusun berdasarkan urutan kekeluargaan. Rumah yang paling barat adalah keluarga tertua, sementara rumah paling timur adalah keluarga paling muda. Maka urutan barat-timur menunjukkan urutan orang tua, anak-anak, cucu-cucu dan cicit-cicit yang pada umumnya dari keluarga pihak perempuan. ${ }^{27}$

${ }^{26}$ Kualitas kerja seseorang ditentukan oleh manfaatnya dan persesuaian apa yang dikerjakan dengan apa yang diajarkan di dalam al-qur'an dan hadits.

27 Lintu Tulistyantoro, "Makna Ruang Pada Tanean Lanjang Di Madura," Dimensi \begin{tabular}{l|l} 
JURNAL LISAN AL-HAL & 183
\end{tabular} 
Langgar (mushalla) yang terdapat pada tanean lanjhang berfungsi sebagai tempat shalat berjamaah. Selain itu, langgar juga digunakan sebagai tempat kegiatan keagamaan bersama, misalnya kegiatan tadarus, pengajian, dan tahlil. Tidak hanya untuk kegiatan ibadah dan keagamaan, langgar juga berfungsi sebagai tempat aktivitas para orang tua untuk transfer nilai-nilai religi, memberikan nasihat dan pelajaran hidup bagi anak-anaknya, sebagai tempat bekerja di siang hari, tempat istirahat dan tidur bagi laki-laki, dan sebagai tempat menerima tamu. ${ }^{28}$ Bahkan beberapa orang pada keluarga tanean lanjhang, lebih suka tidur dan beristirahat di langgar dari pada di kamar rumahnya, baik di siang hari maupun malam hari.

Langgar/mushalla yang terdapat pada tanean lanjhang terkadang juga berfungsi sebagai surau, tempat anak-anak kampung belajar mengaji. Hal ini apabila si pemilik mushalla/tanean lanjhang termasuk orang yang dituakan dan memiliki kemampuan untuk mengajarkan al-Qur'an. Sehingga mushalla pada tanean lanjhang tidak hanya berfungsi sebagai tempat ibadah dan tempat berkumpulnya anggota keluarga, tetapi juga bisa menjadi lembaga pendidikan informal bagi anak-anak.

\section{Karakteristik Dan Etos Bisnis Keluarga Tanean Lanjhang Di Madura}

Di antara daerah dan pulau yang ada di Indonesia, Madura termasuk salah satu pulau/daerah yang tanahnya kering, cenderung kurang subur dan tidak hijau. Hal ini bisa jadi karena susunan tanahnya yang memang kurang subur untuk tetumbuhan atau bisa jadi juga karena sistem irigasinya yang masih tradisional atau bahkan nyaris tidak ada.

Tanah Madura yang kering dan cenderung kurang subur karena pulaunya yang kecil, sungai-sungai pendek, dan dikelilingi oleh pegunungan yang berupa bukit kapur dengan ketinggian sekitar $470 \mathrm{~m}$

Interior 3, no. 2 (2005), accessed September 29, 2019, http://dimensiinterior.petra.ac.id/index.php/int/article/view/16389. Umumnya anak, cucu dan cicit yang tinggal di tanaen lanjhang itu dari pihak perempuan karena dalam budaya Madura, suami ikut istri. Sehingga penghuni asli di rumah itu (tanean lanjhang) adalah para perempuan, sementara yang laki-laki adalah pendatang (menantu).

28 Jeckhi Heng et al., "Konsepsi Langgar Sebagai Ruang Sakral Pada Tanean Lanjang," Jurnal Arsitektur KOMPOSISI 10 (May 1, 2017): 217-224; Abdul Sattar, "Tanian Lanjang: Pola Tata Ruang dan Kekerabatan Masyarakat Madura," Sabda : Jurnal Kajian Kebudayaan 10, no. 2 (2015), accessed September 28, 2019, https://ejournal.undip.ac.id/index.php/sabda/article/view/13286.

184 JURNAL LISAN AL-HAL 
dari permukaan laut. Bukit-bukit yang ada di pedalaman, pada umumnya lebih tinggi daripada bukit-bukit yang ada di sepanjang pantai. Bukit-bukit yang ada di bagian timur Madura lebih tinggi daripada bukit-bukit yang ada di bagian barat. Di bagian barat, bukit-bukit itu jarang mencapai ketinggian $200 \mathrm{~m}$. Sedangkan di bagian timur, bukit-bukit bahkan bisa lebih dari 200m, seperti gunung Gadu (341m), gunung Marengan (398m), dan gunung Tembuku (471m). Nampaknya, kondisi inilah yang menjadi salah satu penyebab Madura beriklim panas. Suhu udara Madura ketika musim hujan berkisar 28 derajat $\mathrm{C}$ sedangkan pada musim kemarau ratarata sekitar 35 derajat C. ${ }^{29}$

Sedangkan dari sisi irigasi, masyarakat Madura pada umumnya hanya mengandalkan air hujan dan air sumur. Kalaupun ada yang menggunakan sumur, jumlahnya sangat sedikit. Sehingga tanah-tanah terlihat cukup subur dan hijau pada saat musim hujan saja, sementara pada musim kemarau tanahnya menjadi sangat kering dan tandus.

Karena kondisi tanah yang kering, tanah yang cenderung kurang subur, dan sistem irigasi yang masih tradisional dan terbatas, maka pertanian yang berkembang di Madura adalah pertanian tegalan dengan tanaman jagung, tembakau dan jenis kacang-kacangan. Itupun kalau tanaman jagung dan kacang-kacangan dapat dipanen, kalau tidak, tanaman-tanaman itu hanya bisa digunakan untuk pakan ternak. ${ }^{30}$

Kondisi alam yang demikian itu menimbulkan konsekuensi terhadap kehidupan ekonomi mereka. Pertanian yang sulit membuat pangan menjadi berkurang dan sangat terbatas. Terlebih ketika terjadi kemarau panjang yang disertai musim paceklik. Hal inilah yang kemudian menjadi salah satu pendorong orang Madura bermigrasi secara besarbesaran ke berbagai pulau dan daerah di Indonesia pada masa lampau hingga sekarang. Mereka yang tinggal di rumah pada umumnya adalah para orang tua, perempuan dan anak-anak, sedangkan orang laki-lakinya, terutama anak-anak muda kebanyakan merantau. Wajar jika kemudian banyak ditemukan orang Madura di berbagai daerah di Indonesia. ${ }^{31}$

Orang Madura memiliki karakter yang cukup menonjol yang dipengaruhi dan dibentuk oleh paham agama, kondisi alam, budaya dan lingkung sekitarnya. Meski orang Madura tidak semuanya memiliki karakter dan sifat yang sama, namun secara umum dapat digambarkan sebagai berikut :

29 Djakfar, "Etos Bisnis Etnis Madura Perantauan Di Kota Malang."

30 Rochana, "Orang Madura."

31 Ibid. 
1) Orang Madura cenderung kaku dan kasar.

Sifat ini terlihat pada diri orang Madura yang sikapnya cenderung tidak lembut dan tutur katanya tidak lembut. Namun bukan berarti bahwa orang Madura tidak paham etika dan sopan santun, melain karena ini merupakan pembawaan asli dan sudah menjadi karakter. Orang Madura biasanya dalam bersikap dan berperilaku adalah apa adanya, sehingga betul-betul merupakan ekspresi dari isi hatinya. Karena itulah kemudian orang-orang luar Madura melihat dan merasakan sikap dan perilaku yang kaku dan kasar. ${ }^{32}$

Hanya saja, karakter yang demikian itu bisa menimbulkan berbagai persepsi dari orang-orang selain etnis Madura. Bahkan tidak jarang yang muncul kemudian adalah persepsi negatif bahwa orang Madura arogan, kasar dan identik dengan kekerasan. Terutama ketika orang Madura berada atau bahkan tinggal di perantauan (daerah luar Madura). Namun tentu saja bahwa tidak semua persepsi itu benar. Bahkan faktanya bahwa orang Madura akan jauh lebih baik ketika diperlakukan dengan baik, namun bisa sangat buruk ketika diperlakukan dengan tidak baik. Orang Madura akan menjadi sangat keras dan garang jika menyangkut hal-hal yang bersinggungan dengan harga diri. Harga diri bagi orang Madura adalah harta terbesar yang harus dibela dan dipertahankan, apapun risikonya, bahkan ketika risiko itu bernama kematian. Hal-hal yang dianggap dapat melukai harganya dirinya adalah ketika seseorang mengganggu harta pusaka dan perempuannya. Harta pusaka adalah rumah adat, tanah, dan pusaka warisan leluhur, sedangkan perempuan yang dimaksud adalah istri, anak perempuan, saudara perempuan atau kerabat perempuan lainnya. Maka semua itu adalah lambang kehormatan dan identik dengan harga diri para laki-laki Madura. ${ }^{33}$

2) Ambisius dan Pekerja Keras

Di kalangan orang Madura, kata abharenteng (bekerja keras) cukup populer untuk menggambarkan karakter seseorang yang sangat ambisius untuk mewujudkan keinginannya. Hal ini barangkali disebabkan oleh faktor alam, di mana orang madura tidak bisa santai-santai, kerja seadanya dan sebisanya untuk memenuhi kebutuhan hidup. Perlu kerja keras dan perjuangan untuk kemudian bisa hidup dengan kondisi alam (atau bahkan SDM) yang sangat terbatas.

3) Memiliki solidaritas yang tinggi

32 Ainurrahman Hidayat, "Karakter Orang Madura Dan Falsafah Politik Lokal," KARSA: Journal of Social and Islamic Culture 15, no. 1 (March 23, 2012): 1-14.

${ }^{33}$ Rochana, "ORANG MADURA."

$186 \mid$ JURNAL LISAN AL-HAL 
Di antara karakter yang dimiliki oleh orang Madura, yaitu sikap yang senantiasa peduli paa orang lain, baik kerabat maupun tetangga. Maka gotong-royong yang dikenal dengan jhak ajhak sudah biasa sekali ditemukan di kalangan orang Madura, terlebih jika kerabat atau tetangga yang memiliki hajat. Bahkan untuk urusan pertanian, baik di sawah maupun di tegalan, sering kali petani tidak perlu mengeluarkan banyak biaya untuk untuk kuli tani, karena biasanya masyarakat akan bergotongroyong, yang dikenal dengan istilah urunan untuk menggarap sawah.

4) Kukuh (koko)

Sifat ini menggambarkan karakter orang Madura yang teguh memegang prinsip, keyakinan, pendirian dan perkataannya. Karena itu pula orang Madura sangat hormat dan segan pada orang yang teguh memegang prinsip dan bisa "dipegang" kata-katanya, karena itu merupakan sifat seorang ksatria. Sebaliknya, orang yang tidak memiliki prinsip, plinplan dalam mengambil sikap, serta tidak bisa "dipegang" ucapannya tidak memiliki tempat di hati orang Madura. ${ }^{34}$ Maka tidak heran jika orang yang memiliki prinsip, teguh, pemberani dan bisa dipercaya, lebih disukai dan dipilih untuk menjadi pemimpin (kalebun), dari pada orang yang pintar, bahkan sarjana, namun tidak memiliki sifat sebagai seorang ksatria.

5) Apa Adanya

Mayoritas orang Madura, terutama yang tidak merantau ke luar pulau, sangat sedikit berinteraksi dengan orang luar Madura. Hal inilah yang menyebabkan sifat dan sikap orang Madura tidak banyak dipengaruhi oleh budaya luar. Termasuk dalam cara berpakaian, orang Madura (terutama orang desa) sangat mencolok dan terlihat perbedaannya dengan orang luar Madura. Pernah melihat orang di terminal, stasiun dan tempat-tempat umum lainnya memakai sarung? Hampir bisa dipastikan itu adalah orang Madura.

Tidak hanya dalam masalah berpakaian, bersikap dan bertutur kata, orang Madura juga cenderung apa adanya ketika misalnya melakukan hubungan bisnis. Dalam kegiatan bisnis, orang Madura cenderung jujur, baik yang berkaitan dengan harga maupun kualitas barang dagangan. Barangkali, selain disebabkan oleh karakter orang Madura yang apa adanya, hal ini juga dipengaruhi kondisi lingkungan di mana informasi yang terkait dengan kegiatan bisnis itu masih sangat terbatas.

6) Bertanggung jawab

${ }^{34}$ Hidayat, "Karakter Orang Madura Dan Falsafah Politik Lokal."

$$
\begin{array}{l|l}
\text { JURNAL LISAN AL-HAL } & 187
\end{array}
$$


Bagi orang Madura, tanggung jawab adalah bagian dari harga diri, dan dalam tradisi Madura, harga diri setara dengan nyawa. Dalam tradisi keluarga tanean lanjhang (selain sebagai kewajiban agama), laki-laki berkewajiban untuk menafkahi keluarga, sedangkan istri diam di rumah. Jika bekerja di Madura tidak memungkinkan, maka merantau adalah pilihan utama.

Barangkali secara psikologis, setiap laki-laki pada keluarga tanean lanjhang terdorong untuk memperbaiki kehidupan sosial-ekonomi keluarga, karena pada umumnya mereka adalah pendatang di keluarga itu. Rumah-rumah yang dibangun di keluarga tanean lanjhang adalah rumah yang dibangun oleh orang tua untuk anak perempuannya. Sehingga jika saatnya mereka menikah, rumah itu akan ditempati bersama suaminya. Maka wajar kalau kemudian ada bahasa, "menikah dengan gadis Madura, akan dapat istri sekaligus rumah." 35 Karena itu, tanggung jawab seorang laki-laki hanya akan terlihat dari seberapa keras dia berjuang untuk menafkahi dan memperbaiki ekonomi keluarga setelah dia menikah.

Dalam sebuah larik "Pingpilu" yang seringkali dinyanyikan oleh orang Madura, terutama oleh para orang tua jaman dulu: "Pingpilu, ta" endha' nyempang lorongah. Pingpilu, lorongngah tombuwi janggel. Pingpilu, ta'endha' ngala' toronna. Pingpilu, toronna oreng ta' bajeng." D. Zazawi Imron menjelaskan bahwa larik itu mengandung isyarat orang Madura lama tidak mau menerima keturunan orang yang tidak rajin dan tidak becus bekerja. ${ }^{36}$ Bagi orang Madura, bekerja tidak hanya tentang menghasilkan apa dan menjadi siapa, tetapi bekerja adalah pembuktian bahwa seorang laki-laki memiliki tanggung jawab pada keluarganya.

7) Berorientasi pada kerja

Sebagaimana yang dijelaskan sebelumnya, bahwa tanggung jawab seorang laki-laki dinilai dari kerjanya. Seseorang yang bekerja keras untuk menghidupi dan menafkahi keluarga, akan dianggap sebagai orang yang bertanggung jawab. Karena itu bagi sebagian orang Madura, nilai seorang laki-laki bukan terletak pada harta dan kekayaan yang dimilikinya, tetapi dari semangatnya untuk bekerja keras demi keluarga.

Berdasarkan hal itu, sebagian masyarakat Madura dalam berusaha berorientasi pada kerja, bukan pada hasil. Karena sekali lagi, karena kerja melambangkan tanggung jawab laki-laki Madura. Maka tak heran jika kemudian laki-laki yang dengan kehidupan ekonomi pas-pasan tapi memiliki semangat dan militansi yang tinggi dalam bekerja, lebih disukai

${ }^{35}$ Sattar, "Tanian Lanjang : Pola Tata Ruang dan Kekerabatan Masyarakat Madura."

${ }^{36}$ Djakfar, "ETOS BISNIS ETNIS MADURA PERANTAUAN DI KOTA MALANG."

$188 \mid$ JURNAL LISAN AL-HAL 
dari pada laki-laki yang lebih berada secara ekonomi, tetapi malas bekerja.

\section{Peran Agama Dan Sosial-Budaya Dalam Pembentukan Etos Kerja Keluarga Muslim Tanean Lanjhang Di Madura}

Suku Madura dikenal sebagai masyarakat yang sangat religius. Religiusitas ini tergambar salah satunya dalam pesan yang selalu disampaikan oleh para orang tua kepada anak-anaknya agar menjaga shalat di manapun berada dan apapun pekerjaan/kegiatannya. Sebab bagi orang Madura, shalat merupakan salah satu tolak ukur baik atau tidaknya kehidupan yang dijalani oleh seseorang. Jika shalatnya baik, maka baik juga kehidupannya. Namun jika buruk shalatnya, maka buruk juga kehidupannya. Karena itu, ada peribahasa yang juga terkenal di kalangan orang-orang Madura, yaitu "asapo' iman, abhantal syahadat" (berselimutkan iman, berbantal syahadat). ${ }^{37}$

Selain itu, religiusitas orang Madura juga terlihat pada setiap aktivitasnya yang selalu didasarkan nilai-nilai agama, baik dalam aktivitas sosial, politik, ekonomi, bahkan seni, termasuk dalam membangun kesadaran kolektif masyarakat. ${ }^{38}$

Sifat religiusitas ini mengakar dan berjalan beriringan bersama dengan budaya dan adat istiadat yang mereka pegang. Karena itu, akulturasi antara agama dan budaya bisa menjadi kombinasi yang unik di kalangan masyarakat Madura, seperti budaya arebba (shadaqah makanan yang diberikan kepada guru gaji atau tetangga), arokat (melakukan selamatan untuk harta benda misalnya rumah, tanah, hewan ternak, dan lain-lain), nyonyonson (memberikan wewangian sebagai bagian dari sunah nabi dengan menggunakan dupa atau kemenyan), membuat ancak/tottobuan ${ }^{39}$, dan lain sebagainya.

37 Ainurrahman Hidayat, "Jatidiri Orang Madura (Vis a Vis) Industrialisasi," KARSA: Journal of Social and Islamic Culture 16, no. 2 (April 21, 2012): 32-42.

${ }^{38}$ Abd Aziz Faiz, "Pola Dan Logika Nikah Sirri Dalam Kultur Masyarakat Madura," Musãwa Jurnal Studi Gender dan Islam 12, no. 1 (January 29, 2013): 121-136.

${ }^{39}$ Ancak adalah makanan yang ditaruh dalam sebuah wadah (biasanya berbentuk segi empat terbuat dari pelepah pisang). Ancak ini biasanya akan dibuat ketika seseorang hendak memulai usaha atau tani dan akan diletakkan/digantung dipinggir sawah. Ancak ini mirip sesajen, hanya saja, ancak sengaja diperuntukkan/diberikan pada orang yang sedang bekerja atau anak-anak yang lagi bermain di sawah dengan tujuan bersedekah. Ancak dan tottobuan adalah sama. Bedanya, jika ancak digantung, sedangkan tottobuan diletakkan di bawah. 
Kuatnya akulturasi agama dan budaya inilah yang barangkali menjadi salah satu penyebab kuatnya masyarakat Madura dalam berpegang pada nilai-nilai agama. Bahkan sikap religiusitas ini terkadang mengarah kepada sikap fanatisme. Karena itu, jangan heran jika orang Madura lebih memperhatikan ajaran agama yang diajarkan oleh guru ngaji dan diamalkan secara turun temurun dari pada fatwa seorang ulama yang baru didengar.

Etos kerja orang Madura, terutama anggota tanean lanjhang tentu tidak lepas dari pengaruh agama, sikap religiusitas dan sosial-budaya orang madura. Doktrin agama yang diberikan oleh bengaseppo (para orang tua di keluarga) dan guru-guru (terutama guru ngaji/kiai langgar) memiliki peranan penting dalam pembentukan karakter dan etos kerja ini. Sejak kecil, anak-anak dididik untuk tidak menjadi orang lampot (malas), dhalmos (malas, namun lebih parah dari lampot) dan korang ajhar (kurang ajar/tidak sopan). ${ }^{40}$ Barangkali, injeksi etos ini lebih banyak dilakukan melalui pendidikan etika oleh orang-orang tua Madura kepada anak-anak dan keluarganya.

Doktrin-doktrin tersebut diberikan melalui pergaulan sehari-hari, pertemuan keluarga di mushalla tanean lanjhang, maupun di surau-surau tempat mengaji. Selain itu, anak-anak yang sudah cukup umur, biasanya akan dikirim ke pesantren untuk memperdalam ilmu agama. Bagi orang madura, pesantren adalah salah satu lembaga pendidikan yang wajib di jalani oleh anak-anak mereka. Di pesantren inilah kemudian mereka dididik untuk mandiri dan kerja keras.

Dalam paham keagamaan, mayoritas masyarakat Madura beraliran ahlussunnah wal jama'ah al-Nahdliyyah, yakni paham sunni yang dibawa dan diajarkan oleh kiai-kiai NU. ${ }^{41}$ Paham ini yang pada akhirnya

${ }^{40}$ Inilah kearifan lokal yang diajarkan oleh para orang tua pada anak-anak muda secara turun-temurun di Madura. Misalnya, anak muda tidak boleh duduk di atas (lebih tinggi) jika di bawah (di tempat yang lebih rendah) ada orang tua, seseorang yang lewat di depan orang lain (terutama di hadapan orang yang lebih tua) harus membungkukkan badannya, anak muda wajib menggunakan bahasa halus ketika berbicara dengan orang yang lebih tua (bahasa Madura memiliki tiga, bahkan empat tingkatan bahasa), jika menunjuk sesuatu (terutama jika pada orang yang lebih tua) harus menggunakan jempol, dan lain sebagainya. Pelajaran ini begitu kuat tertanam dan menjadi karakter hingga anak-anak menjadi dewasa.

41 Orang madura memiliki fanatisme yang sangat tinggi terhadap NU dan kiai-kiai NU. Karena itu, tak heran jika kemudian ada anekdot Gus Dur bahwa agama orang Madura adalah NU. Sikap fanatisme ini barangkali salah satunya karena Ke-NU-an orang Madura dibangun secara kultural melalui hubungan guru dan murid, antara kiai dan santrinya. Hal ini terlihat misalnya ketika orang Madura ditanya siapa pengurus yang

190 JURNAL LISAN AL-HAL 
membentuk pola pikir masyarakat Madura, bahwa hidup tidak bisa selalu bergantung pada nasib. Meski masyarakat Madura dihadapkan pada kondisi alam dan sumber daya yang serba terbatas, tetapi mereka percaya bahwa manusia memiliki kesempatan dan kemampuan untuk mengubah kondisi sosial-ekonominya dengan ijin Allah.

Paham ini tergambar dalam peribahasa Madura, "mon terro atana'a, atani. Mon terro adhaghinga, adhaghang" (Kalau ingin masak nasi, harus bertani. Kalau ingin "berdaging", harus berdagang). Peribahasa bahasa tersebut menggambarkan bahwa orang Madura tidak akan pasrah dan bergantung hanya pada nasib, tetapi harus berjuang dan berikhtiar untuk mencari rezeki Allah SWT.

\section{Simpulan}

Tanean lanjhang adalah model perumahan di Madura yang terdiri dari beberapa rumah berjajar dan berhadap-hadapan dengan menggunakan satu halaman yang memanjang. Perumahan ini biasanya dihuni oleh satu keluarga besar mulai dari orang tua, anak-anak, cucucucu dan cicit-cicitnya. Di ujung paling barat biasanya terdapat mushalla.

Karena model perumahan yang seperti ini, serta intensitas bertemu di antara mereka yang tinggi, bahkan ada waktu khusus bagi para orang tua untuk memberikan nasihat dan wejangan kepada anak cucunya, membuat ikatan emosional di antara para anggota keluarga tanean lanjhang ini begitu kuat. Hal ini menjadikan transfer nilai-nilai religi, pelajaran hidup dan etos bisnis dari para orang tua menjadi lebih mudah dan efektif.

Di antara karakter etos bisnis keluarga muslim pada tanean lanjhang di Madura adalah teguh pendirian, ambisius, kerja keras, memiliki solidaritas yang tinggi, apa adanya, bertanggung jawab dan berorientasi pada kerja.

Selain karena faktor genetik, karakter dan etos bisnis itu juga dibentuk oleh nilai-nilai ajaran agama, kondisi sosial-budaya, dan tentunya pengaruh keluarga.

\section{DAFTAR PUSTAKA}

Desky, Harjoni. “Pengaruh Etos Kerja Islami Dan Gaya Kepemimpinan

menduduki struktural NU, kebanyakan dari mereka tidak tahu. Namun jika ditanya, siapa kiai-kiai NU, dengan mudah mereka akan menyebutkan. 
Terhadap Kinerja Karyawan Rumah Makan Ayam Lepaas Lhokseumawe." INFERENSI: Jurnal Penelitian Sosial Keagamaan 8, no. 2. December 1, 2014.

Djakfar, Muhammad. "Etos Bisnis Etnis Madura Perantauan Di Kota Malang: Memahami Dialektika Agama Dengan Kearifan Lokal." Iqtishoduna 7, no. 2 (April 9, 2012). Accessed September 20, 2019. http://ejournal.uinmalang.ac.id/index.php/ekonomi/article/view/1739.

Faiz, Abd Aziz. "Pola Dan Logika Nikah Sirri Dalam Kultur Masyarakat Madura." Musãwa Jurnal Studi Gender dan Islam 12, no. 1. (January 29), 2013.

Heng, Jeckhi, Aji Bayu Kusuma, Jeckhi Heng, and Aji Bayu Kusuma. "Konsepsi Langgar Sebagai Ruang Sakral Pada Tanean Lanjang." Jurnal Arsitektur KOMPOSISI 10. May 1, 2017.

Hidayat, Ainurrahman. "Jatidiri Orang Madura (Vis a Vis) Industrialisasi." KARSA: Journal of Social and Islamic Culture 16, no. 2 (April 21), 2012.

-_- "Karakter Orang Madura Dan Falsafah Politik Lokal." KARSA: Journal of Social and Islamic Culture 15, no. 1 (March 23), 2012.

Irham, Mohammad. "Etos Kerja Dalam Perspektif Islam." SUBSTANTIA 14, no. 1 (April 11), 2012.

Jati, Wasisto Raharjo. "Agama Dan Spirit Ekonomi: Studi Etos Kerja Dalam Komparasi Perbandingan Agama." AL QALAM 35, no. 2 (December 31), 2018.

Rochana, Totok. "Orang Madura: Suatu Tinjauan Antropologis." Humanus 11, no. 1. 2012.

Rokhman, Wahibur. "The Effect of Islamic Work Ethics on Work Outcomes." EJBO - Electronic Journal of Business Ethics and Organization Studies (2010). Accessed December 3, 2019. https://jyx.jyu.fi/handle/123456789/25449.

Saifulloh, Muchammad. "Etos Kerja Dalam Perspektif Islam.” Jurnal Sosial Humaniora 3, no. 1 (June 2), 2010.

Sattar, Abdul. "Tanian Lanjang: Pola Tata Ruang dan Kekerabatan Masyarakat Madura." Sabda: Jurnal Kajian Kebudayaan 10, no. 2 (2015). Accessed September 28, 2019. https://ejournal.undip.ac.id/index.php/sabda/article/view/13286.

Sunardi, Didi. "Etos Kerja Islami." JISI: Jurnal Integrasi Sistem Industri 1, no. 1 (February 2, 2014). Accessed September 10, 2019. https://jurnal.umj.ac.id/index.php/jisi/article/view/928.

192 JURNAL LISAN AL-HAL 
Thaib, Erwin Jusuf. "Al-Qur'an Dan As-Sunnah Sebagai Sumber Inspirasi Etos Kerja Islami." Jurnal Dakwah Tabligh 15, no. 1 (June 16), 2014.

Tulistyantoro, Lintu. "Makna Ruang Pada Tanean Lanjang Di Madura." Dimensi Interior 3, no. 2 (2005). Accessed September 29, 2019. http://dimensiinterior.petra.ac.id/index.php/int/article/view/1638 
"Etno-Etik Tanean Lanjheng"

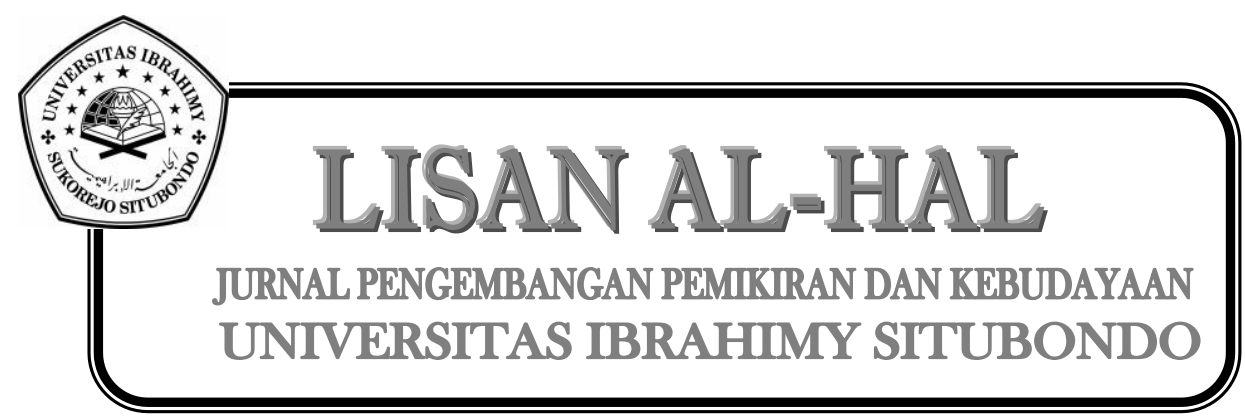

194 JURNAL LISAN AL-HAL 